\title{
X-ray Photoelectron Spectroscopy Study of the Passivation of NiAl(100) by Water Vapor
}

\author{
$\mathrm{Na}$ Cai, ${ }^{\dagger}$ Qianqian Liu, ${ }^{\dagger}$ Xiao Tong, ${ }^{\dagger}$ and Guangwen Zhou ${ }^{*}{ }^{\dagger}$ \\ ${ }^{\dagger}$ Department of Mechanical Engineering \& Multidisciplinary Program in Materials Science and Engineering, State University of New \\ York, Binghamton, New York 13902, United States \\ ${ }^{\ddagger}$ Center for Functional Nanomaterials, Brookhaven National Laboratory, Upton, New York 11973, United States
}

\begin{abstract}
The oxidation of $\mathrm{NiAl}(100)$ surfaces by water vapor is studied using X-ray photoelectron spectroscopy (XPS) to elucidate the effect of temperature and vapor pressure on the surface passivation mechanism of the $\mathrm{NiAl}$ alloy. The water-vapor oxidation at ambient temperature $\left(25{ }^{\circ} \mathrm{C}\right)$ results in self-limiting $\mathrm{Al}(\mathrm{OH})_{3}$ / $\mathrm{Al}_{2} \mathrm{O}_{3}$ bilayer film growth to a less extent of the limiting thickness regimes, in which the growth of the inner $\mathrm{Al}_{2} \mathrm{O}_{3}$ layer occurs via dehydration of the outer $\mathrm{Al}(\mathrm{OH})_{3}$ layer. The growth of the passivating overlayer at the ambient temperature depletes $\mathrm{Al}$ and forms a Ni-rich layer at the oxide/alloy interface that impedes supply of $\mathrm{Al}$ atoms to the outer surface for $\mathrm{Al}(\mathrm{OH})_{3}$ formation via the

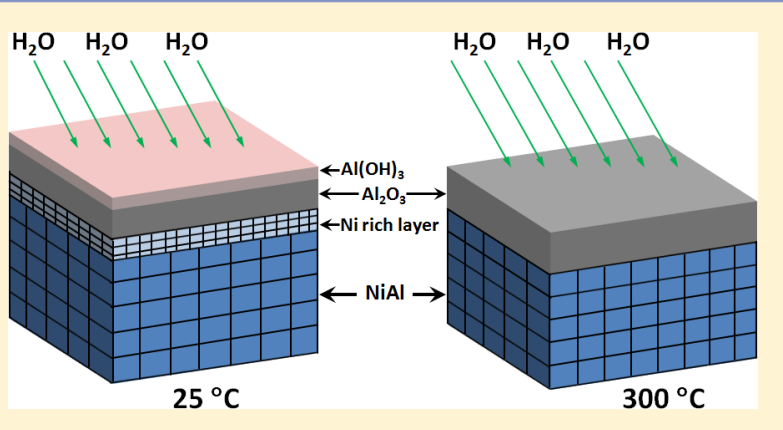
hydration reaction, whereby resulting in a more $\mathrm{Al}$-deficient structure of the outer $\mathrm{Al}(\mathrm{OH})_{3}$ layer upon increasing the vapor pressure. In contrast, the water-vapor oxidation at $300{ }^{\circ} \mathrm{C}$ results in $\mathrm{Al}_{2} \mathrm{O}_{3}$ single-layer film growth to a larger limiting thickness without involving the transient hydroxide phase of $\mathrm{Al}(\mathrm{OH})_{3}$. It is shown that increasing the oxidation temperatures results in the formation of a more compact $\mathrm{Al}_{2} \mathrm{O}_{3}$ film owning to the enhanced bulk diffusion rate that maintains an adequate supply of $\mathrm{Al}$ atoms to the oxide/alloy interface to sustain the oxide film growth to the full extent of the limiting thickness.
\end{abstract}

\section{INTRODUCTION}

The interaction of water vapor with metallic surfaces is of broad fundamental and technological interest owning to its significant importance in many fields including corrosion chemistry, heterogeneous catalysis, electrochemistry, and fuel cells. Water adsorption on elemental metals has been extensively discussed in comprehensive reviews. ${ }^{1,2}$ The study of the interaction of water vapor with metallic alloys has been significantly less. Intermetallic compounds, particularly $\mathrm{Ni}-\mathrm{Al}$, have good resistance to oxidation due to the presence of a large $\mathrm{Al}$ "reservoir" that enables the formation of a protective alumina layer. Recent studies showed that water vapor strongly affects the high-temperature oxidation behavior of alumina-forming Ni-based alloys such as the oxidation kinetics, microstructure, growth morphology, and even leading to the oxide spallation.,4 These studies were mostly dealt with extremely high oxidation temperatures, largely driven by understanding the degradation mechanisms of high-temperature alloys under harsh operation conditions (e.g., gas turbine engines). However, many other processes such as aqueous corrosion, catalytic reactions, and fuel cells occur at ambient or middle-range temperatures, and the understanding of the reaction of water vapor with intermetallic alloys at these relatively low temperatures is still very limited. Recent studies showed that the surface chemistry and growth of ultrathin aluminum oxide films on $\mathrm{NiAl}$ can be modified by water exposure at room temperatures. ${ }^{5,6}$

Compound $\mathrm{NiAl}$ is an ordered intermetallic material possessing high melting point, low density, good oxidation and corrosion resistance, and metal-like electrical and thermal conductivity. These properties have made $\mathrm{NiAl}$ an attractive material for high-temperature applications in propulsion systems and gas turbine engines. Meanwhile, surface passivation of $\mathrm{NiAl}$ by water vapor at ambient temperature has also significant technical implications such as surface catalysts, ${ }^{7}$ electronic metallization in semiconductor heterostructures, ${ }^{8,9}$ and corrosion. ${ }^{10,11}$ An improved understanding of the reaction of water vapor with NiAl surfaces at the relatively low temperatures is needed.

Generally, the oxidation of a metallic surface at low temperatures results in self-limiting oxide film growth. This self-limiting oxidation behavior can be well described by the classic Cabrera-Mott model. ${ }^{12}$ According to this model, an electric field is developed across the oxide film as a result of electron tunneling from the metal through the oxide film to adsorbed oxygen that is driven by the potential difference (known as the Mott potential) between the Fermi level of the parent metal substrate and the acceptor levels of chemisorbed oxygen at the surface. This self-generated electric field assists ion migration and makes oxide film growth possible at low temperatures, for which the oxide growth by thermally driven diffusion is negligible. Since the tunneling current decreases exponentially with oxide film thickening, the oxidation virtually

\footnotetext{
Received: October 15, 2013

Revised: December 31, 2013

Published: January 6, 2014
} 
Table 1. Limiting Thicknesses $(\AA)$ of the Oxide Films Attained by Oxidizing the NiAl(100) Surface with Different Vapor Pressures $\left(p\left(\mathrm{H}_{2} \mathrm{O}\right)\right.$ at 25 and $300{ }^{\circ} \mathrm{C}$, Respectively

\begin{tabular}{cccccccc} 
& \multicolumn{5}{c}{$p\left(\mathrm{H}_{2} \mathrm{O}\right)($ Torr $)$} \\
\cline { 2 - 8 } temp $\left({ }^{\circ} \mathrm{C}\right)$ & $1 \times 10^{-8}$ & $1 \times 10^{-7}$ & $1 \times 10^{-6}$ & $1 \times 10^{-5}$ & $1 \times 10^{-2}$ & 1 & 10 \\
25 & 3.68 & 3.69 & 3.69 & 3.69 & 5.80 & 7.01 & 12.23 \\
300 & 4.75 & 5.26 & 5.75 & 6.29 & N/A & N/A & N/A \\
\hline
\end{tabular}

Table 2. Binding Energies $\left(E_{\mathrm{B}}\right)$ and Full Width at Half Maximum (FWHM) of the Component XPS Peaks Used To Fit the Core Level $\mathrm{Al}^{0} 2 \mathrm{p}, \mathrm{Al}^{3+} 2 \mathrm{p}, \mathrm{O} 1 \mathrm{~s}, \mathrm{OH}$, and $\mathrm{Ni}^{0} \mathrm{p}_{3 / 2}$ Spectra and the Relative Intensity Ratios of $\mathrm{Al}^{3+} 2 \mathrm{p} / \mathrm{O} 1 \mathrm{~s}$ and $\mathrm{Al}^{0} 2 \mathrm{p} / \mathrm{Ni}^{0} 3 \mathrm{p}$ for Water Vapor Exposure at $25{ }^{\circ} \mathrm{C}$ with the Different Vapor Pressures $\left(p\left(\mathrm{H}_{2} \mathrm{O}\right)\right)$

\begin{tabular}{|c|c|c|c|c|c|c|c|c|c|c|c|c|}
\hline \multirow[b]{2}{*}{$\begin{array}{c}p\left(\mathrm{H}_{2} \mathrm{O}\right) \\
(\text { Torr })\end{array}$} & \multicolumn{2}{|c|}{$\mathrm{Al}^{0} 2 \mathrm{p}$} & \multicolumn{2}{|c|}{$\mathrm{Al}^{3+} 2 \mathrm{p}$} & \multicolumn{2}{|c|}{ O 1s } & \multicolumn{2}{|c|}{$\mathrm{OH}$} & \multicolumn{2}{|c|}{$\mathrm{Ni} 3 \mathrm{p}_{3 / 2}$} & \multirow[b]{2}{*}{$\begin{array}{c}\mathrm{Al}^{3+} 2 \mathrm{p} / \\
\mathrm{O} 1 \mathrm{~s}\end{array}$} & \multirow[b]{2}{*}{$\begin{array}{l}\mathrm{Al}^{0} 2 \mathrm{p} \\
\mathrm{Ni}^{0} 3 \mathrm{p}\end{array}$} \\
\hline & $\begin{array}{c}E_{\mathrm{B}} \\
(\mathrm{eV})\end{array}$ & $\begin{array}{c}\text { FWHM } \\
(\mathrm{eV})\end{array}$ & $\begin{array}{c}E_{\mathrm{B}} \\
(\mathrm{eV})\end{array}$ & $\begin{array}{c}\text { FWHM } \\
(\mathrm{eV})\end{array}$ & $E_{\mathrm{B}}(\mathrm{eV})$ & $\begin{array}{c}\text { FWHM } \\
(\mathrm{eV})\end{array}$ & $E_{\mathrm{B}}(\mathrm{eV})$ & $\begin{array}{c}\text { FWHM } \\
(\mathrm{eV})\end{array}$ & $\begin{array}{c}E_{\mathrm{B}} \\
(\mathrm{eV})\end{array}$ & $\begin{array}{c}\text { FWHM } \\
(\mathrm{eV})\end{array}$ & & \\
\hline $1 \times 10^{-8}$ & 72.45 & 1.04 & 74.58 & 2.04 & 531.41 & 2.08 & 533.71 & 1.37 & 66.61 & 2.37 & 0.0533 & 0.2334 \\
\hline $1 \times 10^{-7}$ & 72.44 & 1.04 & 74.66 & 2.05 & 531.36 & 2.08 & 533.59 & 1.37 & 66.65 & 2.37 & 0.0555 & 0.2384 \\
\hline $1 \times 10^{-6}$ & 72.43 & 1.04 & 74.58 & 2.03 & 531.33 & 2.08 & 533.59 & 1.37 & 66.57 & 2.37 & 0.0553 & 0.2383 \\
\hline $1 \times 10^{-5}$ & 72.41 & 1.04 & 74.47 & 2.04 & 531.30 & 2.08 & 533.36 & 1.37 & 66.60 & 2.37 & 0.0551 & 0.2388 \\
\hline $1 \times 10^{-2}$ & 72.42 & 1.04 & 74.39 & 2.04 & 531.20 & 2.08 & 533.11 & 1.78 & 66.55 & 2.37 & 0.0560 & 0.2381 \\
\hline 1 & 72.42 & 1.04 & 74.3 & 2.05 & 531.19 & 2.08 & 532.99 & 1.99 & 66.56 & 2.37 & 0.0558 & 0.2370 \\
\hline 10 & 72.45 & 1.04 & 74.24 & 2.04 & 531.10 & 2.08 & 532.80 & 2.17 & 66.75 & 2.37 & 0.0558 & 0.2362 \\
\hline
\end{tabular}

stops at a limiting thickness of the oxide film. While this mechanism has been demonstrated widely for oxidation by gaseous oxygen, this is unclear how it is applicable to the oxidation of intermetallic alloys such as the $\mathrm{NiAl}$ alloy by water vapor, which may involve multiple reactants such as adsorbed hydroxide $\left(\mathrm{OH}_{(\mathrm{ads})}\right)$, hydrogen $\left(\mathrm{H}_{(\mathrm{ads})}\right)$, and oxygen $\left(\mathrm{O}_{(\mathrm{ads})}\right)$ as well as the composition effect, for which $\mathrm{Al}$ and $\mathrm{Ni}$ have different oxygen affinities.

With the aim of developing basic insight into the reaction mechanism of water vapor with the NiAl alloy, we conduct a comparative study of the oxidation of $\mathrm{NiAl}(100)$ by water vapor at two temperatures, 25 and $300{ }^{\circ} \mathrm{C}$, with the vapor pressure varying from $1 \times 10^{-8}$ to 10 Torr. Using X-ray photoelectron spectroscopy (XPS), the oxidation kinetics and the oxide film limiting thicknesses are determined at the two different temperatures for each vapor pressure. Detailed analyses of the spectral features and binding energies reveal that the oxide film stoichiometry, limiting thickness, interfacial composition, and reaction mechanism bear strong dependence on the oxidation conditions (temperature and water vapor pressure). These results suggest that the self-limiting growth of the oxide overlayer depends on the establishment of the Mott potential across the oxide film that controls the transport of atoms in the oxide film and also on the transport of atoms by bulk diffusion in the alloy substrate. The study demonstrates that passivation properties of an alloy surface can be manipulated either by controlling the reaction temperature or vapor pressure, or both, and by the alloy composition.

\section{EXPERIMENTAL SECTION}

The experiments were performed in an ultrahigh-vacuum chamber equipped with an X-ray photoelectron spectroscopy (XPS) SPECS Phoibos 100 electron energy analyzer and an Ar ion gas sputtering gun. The chamber has a typical base pressure of $2 \times 10^{-10}$ Torr. A nonmonochromatized $\mathrm{Al} \mathrm{K} \alpha \mathrm{X}$-ray source $(h \nu=1486.6 \mathrm{eV})$ was used for the XPS studies. The $\mathrm{NiAl}(100)$ single crystal is a "top-hat" disk (1 $\mathrm{mm}$ thick and $8 \mathrm{~mm}$ in diameter), purchased from Princeton scientific Corp., cut to within 0.1 to the (100) crystallographic orientation and polished to a mirror finish. The sample was heated via a ceramic button heater, and its temperature was monitored with a type $\mathrm{K}$ thermocouple. The crystal was cleaned by cycles of $\mathrm{Ar}^{+}$sputtering $(5 \times$
$10^{-6}$ Torr of $\mathrm{Ar}^{+}, 1 \mu \mathrm{A} \mathrm{cm} \mathrm{cm}^{-2}, 1.0 \mathrm{keV}$ ) followed by annealing at 960 ${ }^{\circ} \mathrm{C}$. The surface cleanliness was checked with XPS.

To perform the water vapor exposure, water (18.2 M $)$ ) was put into a glass flask (ACE) and further purified with several freezepump-thaw cycles before dosing through a variable pressure leak valve. An ion gauge was used to measure the gas pressure in the dosing chamber (note that the effect of the ion gauge sensitivity correction is not accounted for during the pressure measurements due to the minor difference in the gas correction factor for $\mathrm{H}_{2} \mathrm{O}=1.12$ relative to $\mathrm{N}_{2}=$ 1.00). The water vapor exposure was carried out at 25 and $300{ }^{\circ} \mathrm{C}$. The film thickness is determined by the attenuation of the metallic $\mathrm{Al}$ $2 p$ XPS peak of the oxide films with the photoelectron attenuation length for $\mathrm{Al}_{2} \mathrm{O}_{3}(\lambda=16.7 \pm 0.6 \AA)^{13,14}$ by using the formula $d=-\lambda$ $\cos \theta \ln \left(A / A_{0}\right)$, where $A$ is the area of Al metallic peak after oxygen exposure, $A_{0}$ is the area of the $\mathrm{Al}$ metallic peak before oxygen exposure, $\lambda$ is the inelastic mean free path, and $\theta$ is the angle between the analyzer and the sample surface normal, $0^{\circ}$ in our geometry. Angleresolved XPS measurements were made by varying the takeoff angles of the analyzed photoelectrons with respect to the sample surface. Survey photoemission spectra were performed on freshly cleaned and oxidized $\mathrm{NiAl}(100)$ surfaces, which reveal that the surfaces were free of organic contamination.

\section{RESULTS}

The freshly cleaned $\mathrm{NiAl}(100)$ crystal is oxidized by water vapor at the vapor pressure, $\mathrm{pH}_{2} \mathrm{O}$, varying from $1 \times 10^{-8}$ to 10 Torr at $25^{\circ} \mathrm{C}$ and from $1 \times 10^{-8}$ to $1 \times 10^{-5}$ Torr at $300{ }^{\circ} \mathrm{C}$. Meanwhile, a stepwise increase in pressure during water vapor exposure is also used to examine the effect of water vapor pressure on the oxide film growth. For this purpose, the oxidation starts from a freshly cleaned surface at $p\left(\mathrm{H}_{2} \mathrm{O}\right)=1 \times$ $10^{-8}$ Torr, and a limiting thickness of the oxide film is established after long-time vapor exposure. The vapor pressure in the chamber is then increased to a higher pressure, and the limiting thickness of the oxide film reached at this pressure is measured. Each time after reaching a limiting oxide-film thickness, a stepwise increasing in water vapor pressure is applied until $p\left(\mathrm{H}_{2} \mathrm{O}\right)=10$ Torr for the oxidation at $25^{\circ} \mathrm{C}$ and $p\left(\mathrm{H}_{2} \mathrm{O}\right)=1 \times 10^{-5}$ Torr for $300{ }^{\circ} \mathrm{C}$ (due to the limitation by the experimental apparatus, the oxidation at the vapor pressure higher than $1 \times 10^{-5}$ Torr is not examined at $300^{\circ} \mathrm{C}$ ). Table 1 lists the limiting thicknesses of the oxide films attained at 25 
Table 3. $E_{\mathrm{B}}$ and FWHM of the Component XPS Peaks Used To Fit the Core Level $\mathrm{Al}^{0} 2 \mathrm{p}, \mathrm{Al}^{3+} 2 \mathrm{p}, \mathrm{O}_{1 \mathrm{~s}}$, and Ni $\mathrm{p}_{3 / 2} \mathrm{Spectra}^{0}$ and the Relative Intensity Ratios of $\mathrm{Al}^{3+} 2 \mathrm{p} / \mathrm{O}$ 1s and $\mathrm{Al}^{0} 2 \mathrm{p} / \mathrm{Ni}^{0} 3 \mathrm{p}$ for Water Vapor Exposure at $300{ }^{\circ} \mathrm{C}$ with the Different Vapor Pressures $\left(p\left(\mathrm{H}_{2} \mathrm{O}\right)\right)$

\begin{tabular}{|c|c|c|c|c|c|c|c|c|c|c|}
\hline \multirow[b]{2}{*}{$p\left(\mathrm{H}_{2} \mathrm{O}\right)$ (Torr) } & \multicolumn{2}{|c|}{$\mathrm{Al}^{0} 2 \mathrm{p}$} & \multicolumn{2}{|c|}{$\mathrm{Al}^{3+} 2 \mathrm{p}$} & \multicolumn{2}{|c|}{$\mathrm{O} 1 \mathrm{~s}$} & \multicolumn{2}{|c|}{$\mathrm{Ni} 3 \mathrm{p}_{3 / 2}$} & \multirow[b]{2}{*}{$\mathrm{Al}^{3+} 2 \mathrm{p} / \mathrm{O} 1 \mathrm{~s}$} & \multirow[b]{2}{*}{$\mathrm{Al}^{0} 2 \mathrm{p} / \mathrm{Ni}^{0} 3 \mathrm{p}$} \\
\hline & $E_{\mathrm{B}}(\mathrm{eV})$ & FWHM (eV) & $E_{\mathrm{B}}(\mathrm{eV})$ & FWHM $(\mathrm{eV})$ & $\overline{E_{\mathrm{B}}(\mathrm{eV})}$ & $\overline{\text { FWHM }(\mathrm{eV})}$ & $E_{\mathrm{B}}(\mathrm{eV})$ & FWHM $(\mathrm{eV})$ & & \\
\hline $1 \times 10^{-8}$ & 72.43 & 1.05 & 75.08 & 1.66 & 531.68 & 2.12 & 66.49 & 2.3 & 0.0648 & 0.3100 \\
\hline $1 \times 10^{-7}$ & 72.42 & 1.05 & 75.11 & 1.76 & 531.73 & 2.12 & 66.46 & 2.3 & 0.0650 & 0.3185 \\
\hline $1 \times 10^{-6}$ & 72.34 & 1.05 & 75.31 & 1.63 & 531.80 & 2.12 & 66.40 & 2.3 & 0.0654 & 0.3193 \\
\hline $1 \times 10^{-5}$ & 72.39 & 1.05 & 75.16 & 1.57 & 531.86 & 2.12 & 66.38 & 2.3 & 0.0651 & 0.3194 \\
\hline
\end{tabular}

and $300{ }^{\circ} \mathrm{C}$ for the different water vapor pressures. XPS measurements are performed with the $\mathrm{NiAl}(100)$ surface being exposed to different water vapor pressures for different time periods. The $\mathrm{Al} 2 \mathrm{p}, \mathrm{Ni} 2 \mathrm{p}, \mathrm{Ni} 3 \mathrm{p}$, and $\mathrm{O}$ 1s peaks are monitored to investigate changes in spectral features and binding energies due to the water vapor oxidation. Binding energies and full width at half-maximum (FWHM) values of the component peaks, and the relative intensity ratios of $\mathrm{Al}^{3+} 2 \mathrm{p} / \mathrm{O} 1 \mathrm{~s}$ and $\mathrm{Al}^{0}$ $2 \mathrm{p} / \mathrm{Ni}^{0} 3 \mathrm{p}$ determined from the experimental XPS spectra are compiled in Tables 2 and 3 for the different vapor pressures for the water vapor exposure at 25 and $300{ }^{\circ} \mathrm{C}$.

Figure 1 shows representative XPS spectra of $\mathrm{Ni} 2 \mathrm{p}$ core level peaks obtained from a freshly cleaned $\mathrm{NiAl}(100)$ surface and

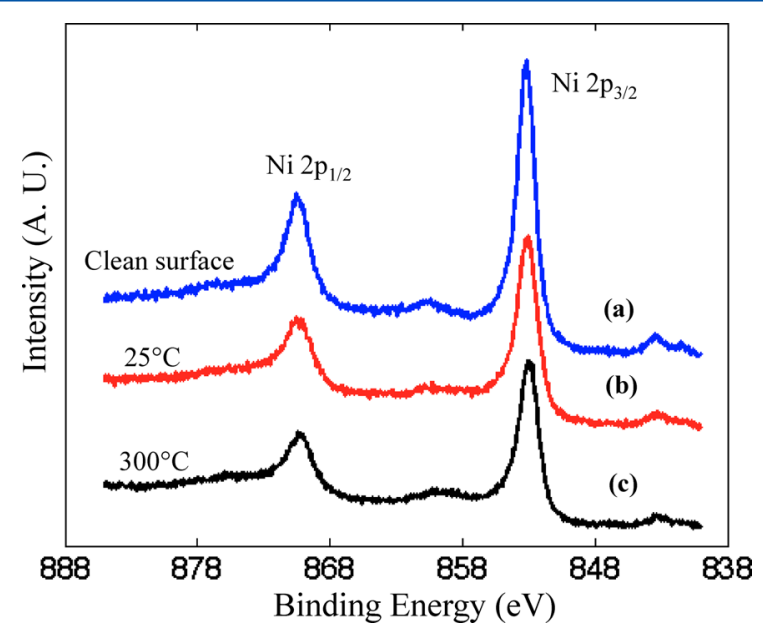

Figure 1. Photoemission spectra of the $\mathrm{Ni} 2 \mathrm{p}$ core level region obtained from (a) the freshly cleaned $\mathrm{NiAl}(100)$ surface, (b) water vapor exposure at $p\left(\mathrm{H}_{2} \mathrm{O}\right)=1 \times 10^{-5}$ Torr and $25^{\circ} \mathrm{C}$ for $125 \mathrm{~min}$, and (c) water vapor exposure at $p\left(\mathrm{H}_{2} \mathrm{O}\right)=1 \times 10^{-5}$ Torr and $300^{\circ} \mathrm{C}$ for $125 \mathrm{~min}$.

the $\mathrm{NiAl}(100)$ surface oxidized to the limiting thicknesses of the oxide films in $p\left(\mathrm{H}_{2} \mathrm{O}\right)=1 \times 10^{-5}$ Torr at $T=25$ and 300 ${ }^{\circ} \mathrm{C}$, respectively. The shape and position of the Ni $2 \mathrm{p}$ core level peaks remain all the same for the two oxidation temperatures. In addition, no oxidic $\mathrm{Ni} 2 \mathrm{p}$ peaks are observed at higher binding energies, indicating that $\mathrm{Ni}$ is not oxidized and remains its metallic state under the all oxidation conditions examined in this work. However, the intensity of the Ni $2 p$ peaks decreases due to the water vapor exposures, suggesting that the $\mathrm{NiAl}$ surface develops an aluminum oxide overlayer and its thickness increases with increasing the oxidation temperature.

Figure 2 shows representative XPS spectra of $\mathrm{Al} 2 \mathrm{p}$ and $\mathrm{Ni}$ $3 p$ core level peaks obtained from the $\mathrm{NiAl}(100)$ surface oxidized to the limiting thicknesses for different water vapor pressures at 25 and $300{ }^{\circ} \mathrm{C}$, respectively. The positions of the metallic $\mathrm{Al} 2 \mathrm{p}$ peak for the water vapor exposure are nearly constant while its intensity decreases with increasing the water vapor pressure for both temperatures. On the other hand, the oxidic $\mathrm{Al} 2 \mathrm{p}$ peak at a higher binding energy becomes visible with the water vapor exposure. Upon increasing the water vapor pressure from $1 \times 10^{-8}$ to $1 \times 10^{-5}$ Torr, the oxidic Al $2 \mathrm{p}$ intensity remains almost unchanged for the oxidation at $25^{\circ} \mathrm{C}$, whereas it increases appreciably for the reaction at $300{ }^{\circ} \mathrm{C}$, suggesting that the growth of the passivation film has a much stronger water vapor-pressure dependence at the higher temperature.

For better comparison of the temperature effect on the binding energies of the $\mathrm{Al}$ and $\mathrm{Ni}$ peaks, Figure 3 shows photoemission spectra of the $\mathrm{Al} 2 \mathrm{p}$ and $\mathrm{Ni} 3 \mathrm{p}$ core level peaks obtained from the oxide films after attaining their limiting thicknesses under $p\left(\mathrm{H}_{2} \mathrm{O}\right)=1 \times 10^{-5}$ Torr at 25 and $300{ }^{\circ} \mathrm{C}$, respectively. Table 4 lists all the fitting parameters for all the core level spectra for identifying the different peaks and binding energies for the water vapor exposure at $p\left(\mathrm{H}_{2} \mathrm{O}\right)=1 \times 10^{-5}$ Torr. The $\mathrm{Al}^{0} 2 \mathrm{p}$ to $\mathrm{Ni}^{0} 3 \mathrm{p}$ intensity ratio at $25{ }^{\circ} \mathrm{C}$ appears larger than that at $25{ }^{\circ} \mathrm{C}$. This difference is mainly caused by the different limiting thicknesses of the oxide films, i.e., 3.69 and $6.29 \AA$, at 25 and $300{ }^{\circ} \mathrm{C}$, as listed in Table 1 . Note that the ratio of the total $\mathrm{Al}$ peak intensity (including metallic and oxidic $\mathrm{Al})$ to the $\mathrm{Ni}^{0} 3 \mathrm{p}$ peak intensity actually increases for water vapor exposure from 25 to $300{ }^{\circ} \mathrm{C}$, indicating that $\mathrm{Al}$ segregates from the bulk alloy to the oxide/substrate interface to form more oxide at $300{ }^{\circ} \mathrm{C}$.

Figure 3 shows that the position of the metallic $\mathrm{Al} 2 \mathrm{p}$ peaks remains constant for the two temperatures. In contrast, the $\mathrm{Ni}$ $3 p$ peak measured from the water vapor exposure at $300{ }^{\circ} \mathrm{C}$ shifts to a lower binding energy $(=66.38 \mathrm{eV})$ compared to that of $25{ }^{\circ} \mathrm{C}(=66.60 \mathrm{eV})$. This binding energy shift of the Ni peak is similar as the temperature-dependent binding-energy shifting observed during the oxidation of $\mathrm{NiAl}(100)$ by oxygen gas. ${ }^{15}$ Bulk NiAl exhibits both ionic and covalent bonding due to a loss of electron density at the $\mathrm{Al}$ positions and gain at the $\mathrm{Ni}$ positions. ${ }^{16}$ Compared to pure $\mathrm{Ni}$, a smaller binding energy can be expected for $\mathrm{Ni}$ in $\mathrm{NiAl}$ due to the increased electron density surrounding $\mathrm{Ni}$ atoms that increases the Coulomb repulsion with the cores and thus reduces the binding energy. Therefore, the temperature-dependent shifting of the binding energy of the metallic Ni peak suggests that there is a Ni-rich layer at the oxide/substrate interface for water vapor exposure at $25{ }^{\circ} \mathrm{C}$ while a more stoichiometric $\mathrm{NiAl}$ interfacial layer for water vapor exposure at $300{ }^{\circ} \mathrm{C}$ (note that the binding energy of the metallic $\mathrm{Al}$ peak remains the same for both cases because $\mathrm{Al}$ atoms are kept in relatively stoichiometric $\mathrm{NiAl}$ for both the two temperatures). It can be also noted from Figure 3 that there is a binding energy shift for the oxidic Al $2 p$ peaks obtained from the passivating films formed at the two temperatures. The binding energy of the $\mathrm{Al} 2 \mathrm{p}$ oxidic peak is $74.5 \mathrm{eV}$ for the passivating film formed from the water vapor 


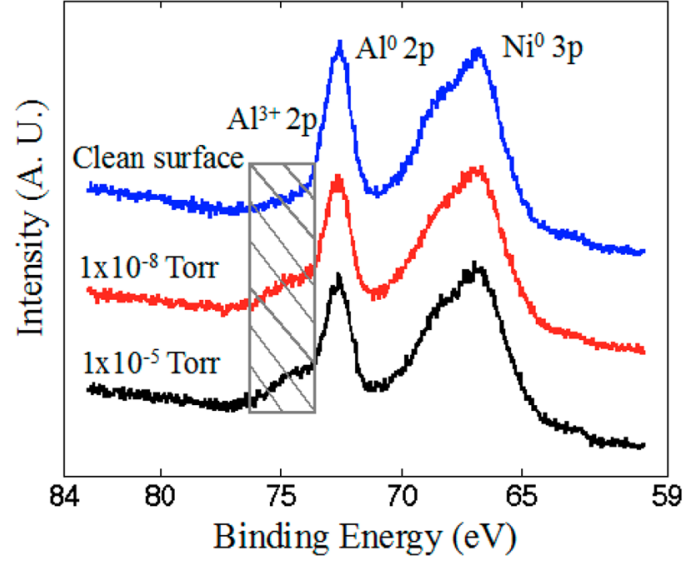

(a)

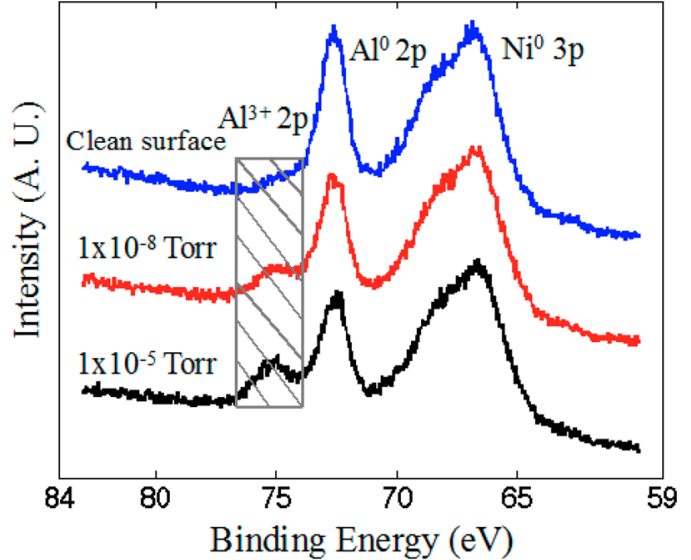

(b)

Figure 2. Photoemssion spectra of the $\mathrm{Al} 2 \mathrm{p}$ and $\mathrm{Ni} 3 \mathrm{p}$ core level regions for the freshly cleaned $\mathrm{NiAl}(100)$ surface and after extended exposures $\left(415 \mathrm{~min}\right.$ ) to water vapor at the indicated water vapor pressure and temperature (a) $\mathrm{T}=25{ }^{\circ} \mathrm{C}$ and (b) $\mathrm{T}=300{ }^{\circ} \mathrm{C}$.

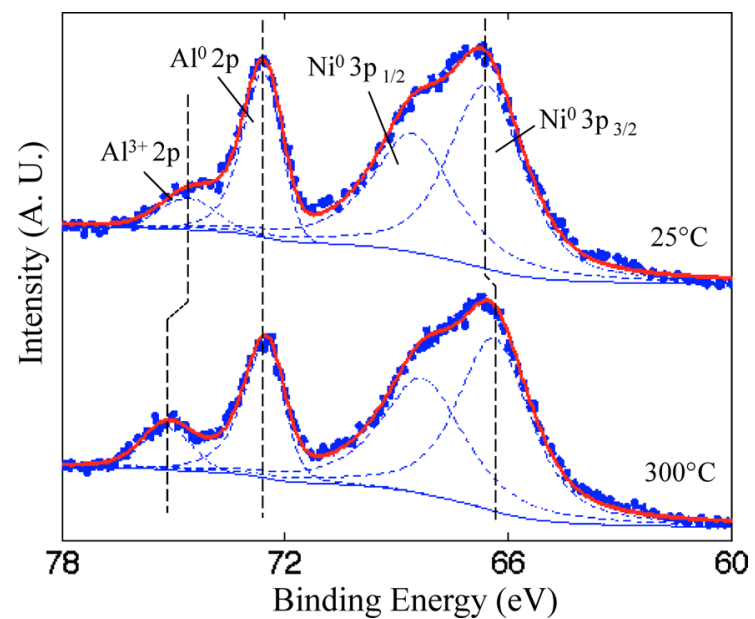

Figure 3. Photoemission spectra of the $\mathrm{Al} 2 \mathrm{p}$ and $\mathrm{Ni} 3 \mathrm{p}$ regions for extended water vapor exposure $(415 \mathrm{~min})$ under the water vapor pressure $p\left(\mathrm{H}_{2} \mathrm{O}\right)=1 \times 10^{-5}$ Torr and $\mathrm{T}=25$ and $300{ }^{\circ} \mathrm{C}$, respectively. The metallic $\mathrm{Al}^{0} 2 \mathrm{p}$ peak remains constant, while the metallic $\mathrm{Ni}^{0} 3 \mathrm{p}_{3 / 2}$ peak shifts to a lower binding energy and the oxidic $\mathrm{Al}^{3+} 2 \mathrm{p}$ peak shifts to a higher binding energy for the passivating film formed at the higher oxidation temperature as revealed by the deconvoluted peaks.

Table 4. Fitting Parameters for Core Level O 1s, $\mathrm{OH}, \mathrm{Al}^{0} 2 \mathrm{p}$, $\mathrm{Al}^{3+} 2 \mathrm{p}, \mathrm{Ni}^{0} \mathrm{p}_{3 / 2}$, and $\mathrm{Ni}^{0} \mathrm{p}_{1 / 2}$ Spectra Obtained from the Oxide Films Grown by Water Vapor at $p\left(\mathrm{H}_{2} \mathrm{O}\right)=1 \times 10^{-5}$ Torr

\begin{tabular}{|c|c|c|c|c|c|c|}
\hline \multirow{2}{*}{$\begin{array}{c}\text { temp } \\
\left({ }^{\circ} \mathrm{C}\right) \\
25\end{array}$} & \multirow[b]{2}{*}{ O 1s } & \multirow{2}{*}{$\begin{array}{c}\text { peak position } \\
(\mathrm{eV}) \\
531.30\end{array}$} & \multirow{2}{*}{$\begin{array}{c}\text { FWHM } \\
(\mathrm{eV}) \\
2.08\end{array}$} & \multirow{2}{*}{$\begin{array}{c}\mathrm{L}-\mathrm{G} \% \\
0\end{array}$} & \multicolumn{2}{|c|}{$\begin{array}{l}\text { asymmetry } \\
\text { factor }\end{array}$} \\
\hline & & & & & 0.25 & 50 \\
\hline & $\mathrm{OH}$ & 533.36 & 1.37 & 0 & 0 & 0 \\
\hline & $\mathrm{Al}^{0} 2 \mathrm{p}$ & 72.41 & 1.04 & 23 & 0.25 & 60 \\
\hline & $\mathrm{Al}^{3+} 2 \mathrm{p}$ & 74.47 & 2.04 & 0 & 0 & 0 \\
\hline & $\mathrm{Ni} 3 \mathrm{p}_{3 / 2}$ & 66.60 & 2.37 & 55 & 0 & 0 \\
\hline & $\mathrm{Ni} 3 \mathrm{p}_{1 / 2}$ & 68.58 & 2.6 & 80 & 0 & 0 \\
\hline \multirow[t]{5}{*}{300} & $\mathrm{O} 1 \mathrm{~s}$ & 531.86 & 2.12 & 11 & 0.2 & 50 \\
\hline & $\mathrm{Al}^{0} 2 \mathrm{p}$ & 72.39 & 1.05 & 23 & 0.25 & 50 \\
\hline & $\mathrm{Al}^{3+} 2 \mathrm{p}$ & 75.16 & 1.57 & 8 & 0 & 0 \\
\hline & $\mathrm{Ni} 3 \mathrm{p}_{3 / 2}$ & 66.38 & 2.30 & 61 & 0 & 0 \\
\hline & $\mathrm{Ni} 3 \mathrm{p}_{1 / 2}$ & 68.31 & 2.6 & 73 & 0 & 0 \\
\hline
\end{tabular}

exposure at $25^{\circ} \mathrm{C}$, while it shifts to a higher binding energy of $75.1 \mathrm{eV}$ for the passivating film formed at $300{ }^{\circ} \mathrm{C}$. A similar trend of shifting to higher binding energies of the oxidic $\mathrm{Al}^{3+} 2 \mathrm{p}$ and $\mathrm{O} 1 \mathrm{~s}$ peaks with increasing the oxidation temperature was also observed from the oxidation of $\mathrm{NiAl}(100)$ by oxygen gas. ${ }^{15}$ The cause of the chemical shift to the higher binding energy is attributed to the formation of more compact alumina film, which is discussed later.

Figure 4 illustrates representative photoemission spectra of the $\mathrm{O}$ 1s core level region obtained from the limiting-thickness

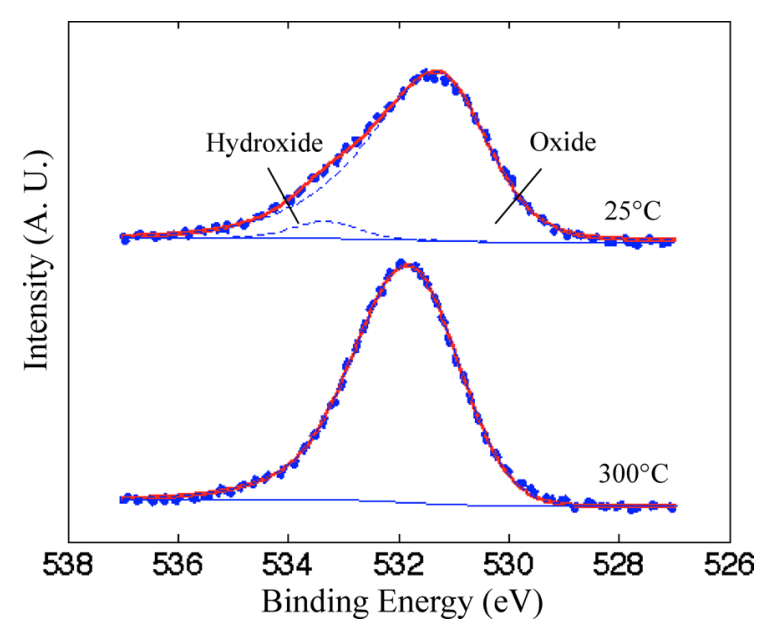

Figure 4. Photoemission spectra of the $\mathrm{O} 1 \mathrm{~s}$ core level region for extended water vapor exposure $(400 \mathrm{~min})$ under the water vapor pressure $p\left(\mathrm{H}_{2} \mathrm{O}\right)=1 \times 10^{-5}$ Torr and $\mathrm{T}=25$ and $300{ }^{\circ} \mathrm{C}$, respectively. The $\mathrm{O} 1 \mathrm{~s}$ XPS spectrum obtained from the water vapor exposure at $25{ }^{\circ} \mathrm{C}$ shows a peak that is broadened to the higher binding energy side and is deconvoluted into two peaks. The oxidic $\mathrm{O}$ 1s peak shifts to a higher binding energy for the passivating film formed at $300{ }^{\circ} \mathrm{C}$ as revealed by the deconvoluted peaks.

passivating films on the $\mathrm{NiAl}(100)$ surface exposed to water vapor at $p\left(\mathrm{H}_{2} \mathrm{O}\right)=1 \times 10^{-5}$ Torr and the temperatures of 25 and $300{ }^{\circ} \mathrm{C}$, respectively. It can be seen that the $\mathrm{O} 1 \mathrm{~s}$ spectra obtained from the $\mathrm{NiAl}(100)$ surface with the water vapor exposure at $25{ }^{\circ} \mathrm{C}$ are less symmetrical and show broadening to the high binding energy side compared to the spectra obtained from the vapor exposure at $300{ }^{\circ} \mathrm{C}$. Since the oxidic O 1 s 
spectra show dependence on temperature, even for oxidation by pure oxygen due to the temperature effect on the microstructure evolution of the oxide films (i.e., less compact oxide film formed at a lower temperature), ${ }^{15}$ we therefore use the same fitting parameters (e.g., FWHM, L-G\%, and asymmetry of the $\mathrm{O} 1 \mathrm{~s}$ peak) of the $\mathrm{O} 1 \mathrm{~s}$ spectra obtained from the oxide film grown on $\mathrm{NiAl}(100)$ from the oxidation at $25{ }^{\circ} \mathrm{C}$ with oxygen gas, which do not provide an overall good fitting to the $\mathrm{O} 1 \mathrm{~s}$ peak obtained from the water vapor exposure at $25^{\circ} \mathrm{C}$, and a second peak at the higher binding energy arises. We have thus deconvoluted the spectra into two peaks, with the binding energies of 531.3 and $533.6 \mathrm{eV}$, respectively. The main peak at $531.3 \mathrm{eV}$ is attributed to oxygen in $\mathrm{Al}-\mathrm{O}$ bonds of $\mathrm{Al}_{2} \mathrm{O}_{3}$, and the other peak at $533.6 \mathrm{eV}$ is attributed to oxygen in $\mathrm{Al}-\mathrm{OH}$ bonds of aluminum hydroxide (i.e., $\left.\mathrm{Al}(\mathrm{OH})_{3}\right)^{17-19}$ (as seen later in Figure 6, this hydroxidic peak becomes stronger at the higher vapor pressure). Their difference in the $\mathrm{O} 1 \mathrm{~s}$ spectra suggests that the water vapor exposure at $25{ }^{\circ} \mathrm{C}$ results in the growth of a $\mathrm{Al}(\mathrm{OH})_{3} / \mathrm{Al}_{2} \mathrm{O}_{3}$ bilayer passivating film on the $\mathrm{NiAl}(100)$ surface.

Using the reference of the $\mathrm{O}$ 1s spectra obtained from the oxide film grown on $\mathrm{NiAl}(100)$ from the oxidation at $300{ }^{\circ} \mathrm{C}$ with oxygen gas, the $\mathrm{O}$ 1s spectra obtained from the water vapor exposure at $300{ }^{\circ} \mathrm{C}$ can be fitted well with one single oxidic $\mathrm{O}$ peak. This peak at the binding energy of $531.8 \mathrm{eV}$ is attributed to oxygen in $\mathrm{Al}-\mathrm{O}$ bonds in $\mathrm{Al}_{2} \mathrm{O}_{3}$, ${ }^{20}$ indicating that the water vapor exposure at $300{ }^{\circ} \mathrm{C}$ results in growth of a $\mathrm{Al}_{2} \mathrm{O}_{3}$ single-layer passivating film on the $\mathrm{NiAl}(100)$. One can note that the $\mathrm{O} 1 \mathrm{~s}$ peak for the water vapor oxidation at $25{ }^{\circ} \mathrm{C}$ is broader compared to that at $300{ }^{\circ} \mathrm{C}$, which may be related to the temperature effect on the microstructure and thickness of the oxide films formed at the two temperatures. A similar temperature effect on the peak shape was also observed from $\mathrm{NiAl}(100)$ oxidation by oxygen gas. ${ }^{15}$ Increasing the oxidation temperature results in the formation of more compact and thicker oxide films and thus narrower peaks of the XPS spectra.

The relative position of each oxide component for the duplex oxide film formed at $25{ }^{\circ} \mathrm{C}$ can be determined by angleresolved XPS. Figure 5 shows the spectra of $\mathrm{O} 1 \mathrm{~s}$ obtained from the oxide film formed from the water vapor oxidation at $p\left(\mathrm{H}_{2} \mathrm{O}\right)=1 \times 10^{-2}$ Torr and $\mathrm{T}=25^{\circ} \mathrm{C}$ for $30 \mathrm{~min}$. The $\mathrm{OH}$ peak associated with hydroxide appears stronger at the larger takeoff angle, and the $\mathrm{OH} / \mathrm{O}$ peak intensity ratio increases from 0.15 to 0.34 as the takeoff angle of analyzed photoelectrons is increased from $0^{\circ}$ to $60^{\circ}$. This indicates that the $\mathrm{OH}$ component is more surface sensitive than the $\mathrm{O}$ component layer; i.e., $\mathrm{Al}(\mathrm{OH})_{3}$ is located on the outer surface of the $\mathrm{Al}_{2} \mathrm{O}_{3}$ layer. The formation of an outer aluminum hydroxide layer was also observed in previous studies on water-induced modifications of ultrathin aluminum oxide films on $\mathrm{NiAl}(100))^{5,6}$ The formation of such a $\mathrm{Al}(\mathrm{OH})_{3} / \mathrm{Al}_{2} \mathrm{O}_{3}$ bilayer passivating film is also consistent with the oxidation of $\mathrm{Al}(111)$ by water vapor at room temperature. ${ }^{21}$

Figure 6 shows the effect of water vapor pressure on the photoemission spectra of the $\mathrm{O} 1 \mathrm{~s}$ peaks obtained from the limiting-thickness passivating films on $\mathrm{NiAl}(100)$. Figure 6a corresponds to the $\mathrm{O} 1 \mathrm{~s}$ spectra of the passivating films formed by water vapor exposure at $25{ }^{\circ} \mathrm{C}$ with a stepwise increase in vapor pressure starting from $p\left(\mathrm{H}_{2} \mathrm{O}\right)=1 \times 10^{-8}$ to 10 Torr. As described in Figure 4, the spectra obtained from the vapor exposure at $25^{\circ} \mathrm{C}$ can be deconvoluted into two peaks, i.e., the $\mathrm{O}$ 1s peak corresponding to oxygen in $\mathrm{Al}_{2} \mathrm{O}_{3}$ and the other peak corresponding to oxygen in $\mathrm{Al}-\mathrm{OH}$. As seen in Figure 6c,

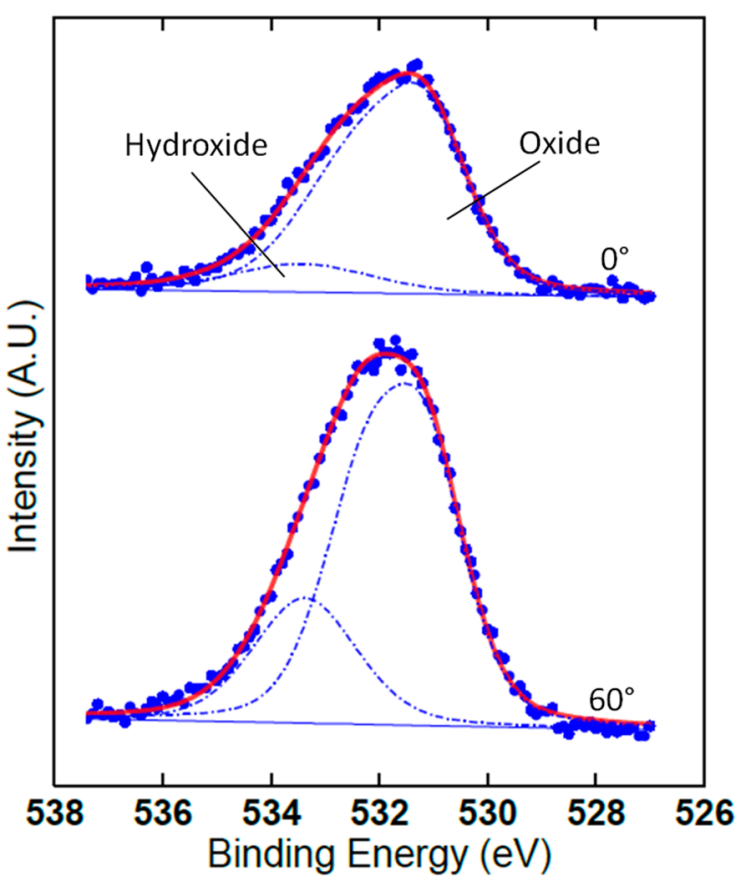

Figure 5. $\mathrm{O}$ 1s core level spectra measured at the takeoff angles of $0^{\circ}$ and $60^{\circ}$ on $\mathrm{NiAl}(100)$ oxidized at $p\left(\mathrm{H}_{2} \mathrm{O}\right)=1 \times 10^{-2}$ Torr and $T=25$ ${ }^{\circ} \mathrm{C}$ for $30 \mathrm{~min}$.

the intensity of the peak associated with $\mathrm{Al}-\mathrm{OH}$ increases with increasing the vapor pressure to the high pressure, suggesting the thickening of the $\mathrm{Al}(\mathrm{OH})_{3}$ layers. The thickening of the outer $\mathrm{Al}(\mathrm{OH})_{3}$ would damp the XPS signal from the inner $\mathrm{Al}_{2} \mathrm{O}_{3}$ layer; however, Figure $6 \mathrm{c}$ shows that the intensity of the peak associated with the $\mathrm{Al}_{2} \mathrm{O}_{3}$ layer remains relatively constant under the oxygen pressures ranging from $1 \times 10^{-8}$ to $1 \times 10^{-5}$ Torr and then becomes stronger for the higher water vapor pressures. This suggests that the inner $\mathrm{Al}_{2} \mathrm{O}_{3}$ layer is also growing and becomes thicker, which thus compensates for the damping effect from the growth of the outer $\mathrm{Al}(\mathrm{OH})_{3}$ layer. Meanwhile, it can be noted from Figure 6a that the $\mathrm{Al}-\mathrm{O}$ peak position remains unchanged for the different vapor pressures while the $\mathrm{Al}-\mathrm{OH}$ peak shifts to lower binding energies with increasing the vapor pressure. Figure $6 \mathrm{~b}$ corresponds to the $\mathrm{O}$ 1s spectra of the passivating films formed by water vapor exposure at $300{ }^{\circ} \mathrm{C}$ with a stepwise increase in water vapor pressure starting from $\mathrm{p}\left(\mathrm{H}_{2} \mathrm{O}\right)=1 \times 10^{-8}$ to $1 \times 10^{-5}$ Torr. All the spectra can be fitted well with the $\mathrm{O} 1 \mathrm{~s}$ peak at the binding energy $\sim 531.8 \mathrm{eV}$, and it can be seen from that the peak intensity (shown in Figure 6d) increases with increasing the water vapor pressure but the peak position remains nearly constant.

Figure 7 shows the evolution of the passivating film thickness determined as described in the Experimental Section as a function of water vapor exposure time and water vapor pressures at 25 and $300{ }^{\circ} \mathrm{C}$, respectively. The vapor exposure starts with a freshly cleaned $\mathrm{NiAl}(100)$ surface at $p\left(\mathrm{H}_{2} \mathrm{O}\right)=1 \times$ $10^{-8}$ Torr. For both temperatures, the passivating films show an initial fast growth stage followed by a reduction in growth rate to the limited growth regime. Once no further changes in thickness are detected, a stepwise increase in water vapor pressure is applied. For passivation at $25{ }^{\circ} \mathrm{C}$, the water vapor exposure at $p\left(\mathrm{H}_{2} \mathrm{O}\right)=1 \times 10^{-8}$ Torr results in a limiting thickness of $\sim 3.69 \AA$, and this limiting thickness of the passivating film remains almost unchanged with increasing the 


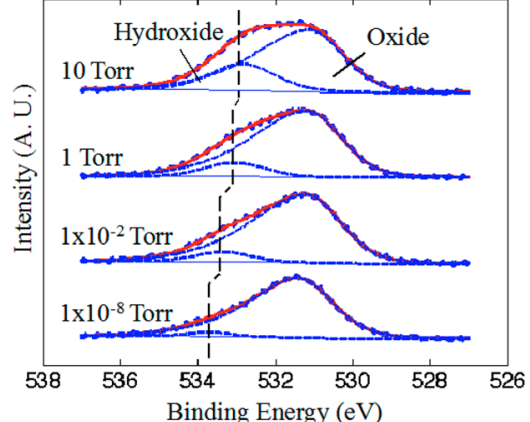

(a)

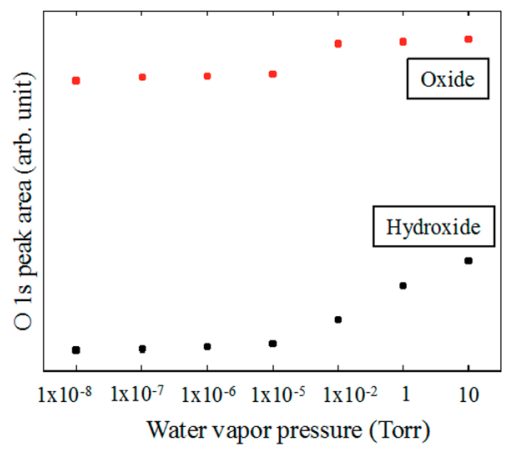

(c)

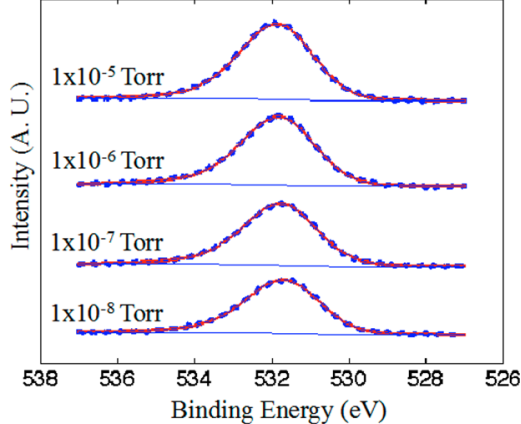

(b)

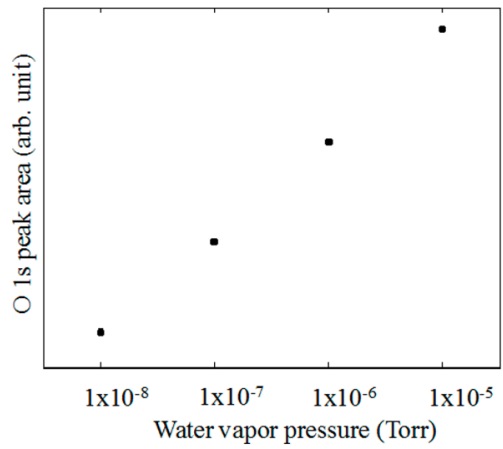

(d)

Figure 6. Photoemission spectra of the $\mathrm{O} 1 \mathrm{~s}$ core level region for extended water vapor exposure (125 min) at the indicated pressures and temperature (a) $\mathrm{T}=25{ }^{\circ} \mathrm{C}$ and (b) $\mathrm{T}=300{ }^{\circ} \mathrm{C}$. The O 1s XPS spectra in (a) show peaks that are broadened to the higher binding energy and are deconvoluted into two peaks, where the oxidic $\mathrm{O}$ 1s peak associated with the oxide (i.e., $\mathrm{Al}_{2} \mathrm{O}_{3}$ ) remains relatively constant at the binding energy of $531.3 \mathrm{eV}$ while the hydroxidic peak shifts to lower binding energies with increasing the water vapor pressure. Intensity evolution of the $\mathrm{O} 1 \mathrm{~s}$ spectra obtained from the oxide films at their limiting thickness for water vapor exposure at (c) $\mathrm{T}=25{ }^{\circ} \mathrm{C}$ and (d) $T=300{ }^{\circ} \mathrm{C}$.

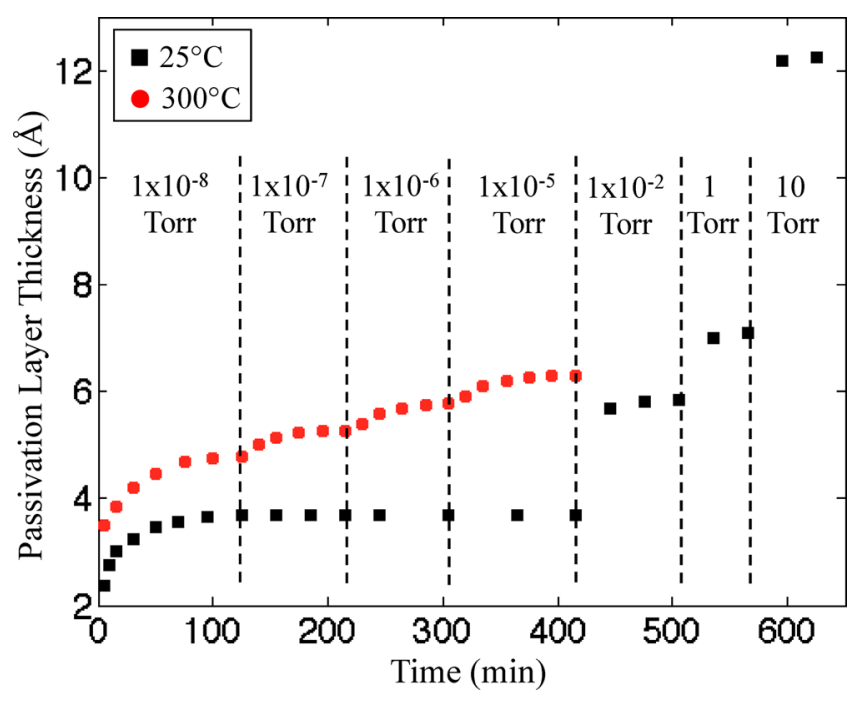

Figure 7. Evolution of the passivating film thickness as a function of oxidation time and water vapor gas pressure during the water vapor exposure at $T=25$ and $300{ }^{\circ} \mathrm{C}$, respectively. The oxidation starts with a freshly clean $\mathrm{NiAl}(100)$ surface which is first oxidized at $p\left(\mathrm{H}_{2} \mathrm{O}\right)=1$ $\times 10^{-8}$ Torr. A stepwise increase in water vapor gas pressure is applied after a limiting passivating film thickness is reached at each water vapor pressure.

water vapor pressure. Only after the water vapor pressure is raised to $1 \times 10^{-2}$ Torr, the passivating film shows growth again and reaches a new limiting thickness. Further increasing the water vapor pressure to 1 Torr and then to 10 Torr results in two thicker limiting thicknesses of the passivation film for each pressure. As shown earlier, the water vapor exposure at $25{ }^{\circ} \mathrm{C}$ results in an $\mathrm{Al}(\mathrm{OH})_{3} / \mathrm{Al}_{2} \mathrm{O}_{3}$ bilayer structure. One would note that the initial limiting thickness of $3.69 \AA$ is less than one unit cell of either $\mathrm{Al}_{2} \mathrm{O}_{3}$ or $\mathrm{Al}(\mathrm{OH})_{3}$, and the thickness does not maintain a periodic atomic structure as a crystal. Since the oxide films formed from the oxidation at the relatively low temperatures are amorphous (as confirmed by low-energy electron diffraction in the experiments), for which a duplex structure consisting of approximately one atomic layer of $\mathrm{Al}-\mathrm{O}$ bonds terminated by a surface layer of $\mathrm{Al}-\mathrm{OH}$ bonds is still physically possible. Even for a crystalline $\mathrm{Al}_{2} \mathrm{O}_{3}$, thin oxide stripes with the thickness as thin as $\sim 1 \AA$ were observed from the oxidation of $\mathrm{NiAl}(100){ }^{22} \mathrm{We}$ also point out that this manner of the increase in the limiting thickness of the oxide film is different from the oxidation of an $\mathrm{Al}(111)$ surface by molecular oxygen or water vapor, for which the limiting thickness of the oxide film remains essentially constant at the pressure of $\sim 1$ Torr for molecular oxygen ${ }^{23,24}$ or $1 \times 10^{-2}$ Torr for water vapor, ${ }^{21}$ irrespective of prolonged oxygen or water vapor exposure and further increase in oxygen or vapor pressure. Although the oxidation of the $\mathrm{NiAl}(100)$ surface by water vapor also shows stepwise growth of the limiting thickness of the passivating film with the stepwise increase in water vapor pressure, we find here that the limiting thickness increases in a stepwise manner only until a water vapor pressure of $p\left(\mathrm{H}_{2} \mathrm{O}\right)=1 \times 10^{-2}$ Torr is reached.

For water vapor exposure at $300{ }^{\circ} \mathrm{C}$, a stepwise increase in vapor pressure in the range from $1 \times 10^{-8}$ to $1 \times 10^{-5}$ Torr results in a corresponding stepwise increase in the limiting thickness for each pressure. It can also be seen in Figure 7 that the water vapor exposure at $300^{\circ} \mathrm{C}$ results in a thicker limiting 
thickness of the passivating film compared to the exposure at 25 ${ }^{\circ} \mathrm{C}$ for the same vapor pressure. This indicates that the reaction kinetics is enhanced at the higher temperature. The oxide films formed on the $\mathrm{NiAl}(100)$ from the oxidation by water vapor at these relatively low temperatures are amorphous in nature and uniformly cover the NiAl substrate as revealed by scanning tunneling microscopy (STM) imaging, similar to the oxide films formed on $\mathrm{NiAl}(100)$ from the oxidation by oxygen gas. ${ }^{15}$

\section{DISCUSSION}

The experimental results described above reveal that the water vapor exposures of the $\mathrm{NiAl}(100)$ surface under the range of the temperatures and water vapor pressures examined result in the selective oxidation of $\mathrm{Al}$ in the $\mathrm{NiAl}$ alloy to form an aluminum oxide passivating overlayer. Thermodynamically, $\mathrm{Al}_{2} \mathrm{O}_{3}$ formation is strongly favored over $\mathrm{NiO}$ formation because of their significant difference in heat of formation, i.e., $-1690.7 \mathrm{~kJ} / \mathrm{mol}$ for $\mathrm{Al}_{2} \mathrm{O}_{3}$ formation vs $-240.8 \mathrm{~kJ} / \mathrm{mol}$ for $\mathrm{NiO}$ formation. ${ }^{25,26}$ The growth of an aluminum oxide layer on the $\mathrm{NiAl}$ surface results in freed $\mathrm{Ni}$ atoms that can accumulate at the oxide/alloy interface or dissolve in the $\mathrm{NiAl}$ bulk at elevated temperatures because the thermodynamically more stable phase in the $\mathrm{NiAl}$ system is the $\mathrm{Ni}$-rich $\mathrm{Ni}_{3} \mathrm{Al}$. For water vapor exposure at the ambient temperature $\left(25^{\circ} \mathrm{C}\right), \mathrm{Al}$ atoms in the near-surface region react with chemisorbed hydroxyl radicals formed via dissociative adsorption of water molecules to form $\mathrm{Al}_{2} \mathrm{O}_{3}$ and $\mathrm{Al}(\mathrm{OH})_{3}$. However, the bulk diffusion of $\mathrm{Al}$ at the ambient temperature is too low to compensate for the loss of $\mathrm{Al}$ at the surface instantaneously. Therefore, a thin Ni-enriched layer is developed at the oxide/substrate interface region. For water vapor exposure at $300{ }^{\circ} \mathrm{C}, \mathrm{Ni}$ dissolves into the bulk at elevated temperatures and $\mathrm{Al}$ segregates to the oxide/substrate interface to compensate the oxidized Al. Thus, the ambienttemperature water vapor dosing results in the formation of a $\mathrm{Ni}$-rich layer at the oxide/alloy interface due to the depletion of $\mathrm{Al}$ for aluminum oxide growth, while the enhanced bulk diffusion during the oxide film growth from the vapor exposure at $300{ }^{\circ} \mathrm{C}$ is sufficient to maintain an equilibrium $\mathrm{NiAl}$ stoichiometry at the oxide/alloy interface. Figure 8 shows

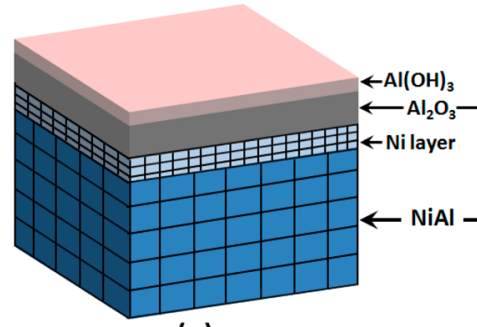

(a)

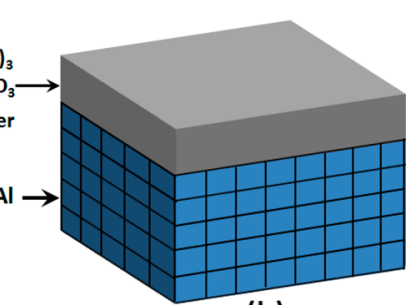

(b)
Figure 8. Schematic illustration of the temperature-dependent interfacial composition and passivating film growth: (a) $\mathrm{T}=25{ }^{\circ} \mathrm{C}$ and (b) $T=300{ }^{\circ} \mathrm{C}$.

schematically the temperature-dependent composition of the interface region, which corroborates well with the observed temperature-dependent binding energy shift of the metallic Ni $3 p$ peak as described in Figure 3.

The temperature dependence of the interfacial alloy composition is also confirmed by quantifying the relative intensity ratios of the metallic $\mathrm{Al}^{0} 2 \mathrm{p}$ and $\mathrm{Ni}^{0} 3 \mathrm{p}$ peaks of the oxidized and clean $\mathrm{NiAl}(100)$ surfaces. Since the XPS sampling depth is typically several nanometers below the surface, we thus use the bulk stoichiometry ratio (i.e., $\mathrm{Al}^{0} / \mathrm{Ni}^{0}=1$ ) as the reference for the relative intensity ratio of the $\mathrm{Al}^{0} 2 \mathrm{p}$ and $\mathrm{Ni}^{0} 3 \mathrm{p}$ peaks from a freshly cleaned $\mathrm{NiAl}$ (i.e., unoxidized). The composition of the alloy underneath the oxide overlayer can be determined from relative intensity ratios of the $\mathrm{Al}^{0} 2 \mathrm{p}$ and $\mathrm{Ni}^{0}$ $3 p$ peaks obtained from the oxidized samples by comparing with the $\mathrm{Al}^{0} 2 \mathrm{p} / \mathrm{Ni}^{0} 3 \mathrm{p}$ intensity ratio of the unoxidized $\operatorname{NiAl}(100){ }^{5,6}$ Using this way, we found that the interfacial alloy compositions are 0.74 (i.e., Ni-rich) and 0.98 (close to the bulk value) for the water vapor oxidation at 25 and $300{ }^{\circ} \mathrm{C}$, respectively. This temperature-dependent interfacial composition is consistent with the work by Maurice et al., who showed that the oxidation of $\mathrm{NiAl}(100)$ by water vapor or liquid water at room temperature results in the depletion of $\mathrm{Al}$ in the alloy below an oxide overlayer, and the $\mathrm{NiAl}$ oxidation in air at 900 ${ }^{\circ} \mathrm{C}$ leads to the rehomogenization of the alloy composition owning to the segregation of metallic $\mathrm{Al}$ from the bulk alloy to the oxide/alloy interface. ${ }^{5,6}$

The adsorption of water vapor on NiAl surfaces at room temperature is reported to be dissociative to form adsorbed $\mathrm{OH}$ radicals and $\mathrm{H}_{2}$ gas that desorbs from the surface $\left(\mathrm{H}_{2} \mathrm{O} \rightarrow\right.$ $\mathrm{OH}_{\mathrm{ads}}+1 /{ }_{2} \mathrm{H}_{2}$ gas $) .{ }^{27-29}$ The reaction between $\mathrm{OH}_{\mathrm{ads}}$ radicals and exposed surface $\mathrm{Al}$ atoms results in the formation of the outer layer of $\mathrm{Al}(\mathrm{OH})_{3}$ via the hydration reaction $\mathrm{Al}+3 \mathrm{OH}_{\mathrm{ads}}$ $\rightarrow \mathrm{Al}(\mathrm{OH})_{3}$. The growth of the inner $\mathrm{Al}_{2} \mathrm{O}_{3}$ layer occurs via dehydration decomposition of the $\mathrm{Al}(\mathrm{OH})_{3}$, i.e., $\mathrm{Al}(\mathrm{OH})_{3} \rightarrow$ $1 /{ }_{2} \mathrm{Al}_{2} \mathrm{O}_{3}+{ }^{3} /{ }_{2} \mathrm{H}_{2} \mathrm{O}$, since the water vapor pressure at the inner interface (i.e., $\mathrm{Al}(\mathrm{OH})_{3} / \mathrm{Al}_{2} \mathrm{O}_{3}$ ) is low and $\mathrm{Al}(\mathrm{OH})_{3}$ is a metastable phase and a hydrated precursor to $\mathrm{Al}_{2} \mathrm{O}_{3}$ formation. ${ }^{30}$ Such a reaction results in an $\mathrm{Al}(\mathrm{OH})_{3} / \mathrm{Al}_{2} \mathrm{O}_{3}$ bilayer structure of the passivating film as shown schematically in Figure 8a. The continued dissociative chemisorption of water molecules leads to the continuous $\mathrm{Al}(\mathrm{OH})_{3}$ formation on the oxide surface, and the dehydration of $\mathrm{Al}(\mathrm{OH})_{3}$ at the $\mathrm{Al}(\mathrm{OH})_{3} /$ $\mathrm{Al}_{2} \mathrm{O}_{3}$ interface via the outward diffusion of $\mathrm{Al}$ cations leads to the growth of the $\mathrm{Al}_{2} \mathrm{O}_{3}$ layer. In addition to the thermodynamic consideration, this interfacial conversion mechanism of $\mathrm{Al}(\mathrm{OH})_{3}$ to $\mathrm{Al}_{2} \mathrm{O}_{3}$ is also inferred from our experimental measurements of the intensity evolution of the $\mathrm{O}$ 1s peaks associated with the $\mathrm{Al}_{2} \mathrm{O}_{3}$ layer and the $\mathrm{Al}(\mathrm{OH})_{3}$ layer as shown in Figures 6a,c, which reveal that both the $\mathrm{Al}(\mathrm{OH})_{3}$ and $\mathrm{Al}_{2} \mathrm{O}_{3}$ layers grow simultaneously with the continued water vapor exposure. Their concomitant growth suggests the interfacial conversion of $\mathrm{Al}(\mathrm{OH})_{3}$ into $\mathrm{Al}_{2} \mathrm{O}_{3}$; otherwise, there will be no $\mathrm{Al}_{2} \mathrm{O}_{3}$ formation due to the lack of $\mathrm{O}$ species from the dissociation of $\mathrm{H}_{2} \mathrm{O}$.

However, the water vapor exposure at $300{ }^{\circ} \mathrm{C}$ results in the growth of a $\mathrm{Al}_{2} \mathrm{O}_{3}$ single layer without detectable $\mathrm{Al}(\mathrm{OH})_{3}$ formation, as revealed from Figure $6 \mathrm{~b}$. The direct $\mathrm{Al}_{2} \mathrm{O}_{3}$ formation without involving the $\mathrm{Al}(\mathrm{OH})_{3}$ precursor at the elevated temperature is both thermodynamically and kinetically favored. It has been shown that the hydrated oxide phase of $\mathrm{Al}(\mathrm{OH})_{3}$ is unstable at temperatures above $300{ }^{\circ} \mathrm{C}$ and transforms to the more stable phase of $\mathrm{Al}_{2} \mathrm{O}_{3},{ }^{30-32}$ and thus the reaction of $2 \mathrm{Al}+3 \mathrm{OH}_{\mathrm{ads}} \rightarrow \mathrm{Al}_{2} \mathrm{O}_{3}+3 /{ }_{2} \mathrm{H}_{2}$ gas is kinetically more favorable without involving the intermediate steps of hydration and dehydration reactions. Meanwhile, the dissociation of water into adsorbed oxygen and gaseous $\mathrm{H}_{2}$, i.e., $\mathrm{H}_{2} \mathrm{O}$ $\rightarrow \mathrm{O}_{\text {ads }}+\mathrm{H}_{\text {2gas, }}$, becomes more dominant at elevated temperatures, ${ }^{33,34}$ which also contributes the direct formation of $\mathrm{Al}_{2} \mathrm{O}_{3}$ via $2 \mathrm{Al}+3 \mathrm{O}_{\mathrm{ads}} \rightarrow \mathrm{Al}_{2} \mathrm{O}_{3}$. Such a process of passivating film growth is schematically shown in Figure $8 \mathrm{~b}$. 
The observed initially fast reaction rate followed by a drastic reduction of the passivating film growth to the limiting oxidefilm thickness at the two oxidation temperatures (Figure 7) is typical for self-limiting film growth under influence of the electric field set up by the negative oxygen ions chemisorbed onto the oxide surface due to electron tunneling through the oxide film (i.e., the Cabrera-Mott model of low-temperature metal oxidation). Indeed, the observed oxide-film growth kinetics are in line with previous studies on the kinetics of oxide-film growth on $\mathrm{NiAl}^{15}$ and $\mathrm{Al}$ substrates, ${ }^{35}$ which showed that the oxidation at temperatures $\leq 300{ }^{\circ} \mathrm{C}$ exhibits selflimiting oxide film growth controlled by electric-field-driven outward diffusion of $\mathrm{Al}$ cations through a close packing of oxygen anions in the amorphous oxide films. For the selflimiting oxide film growth controlled by the electric-field-driven diffusion, it was shown that the actual value of the Mott potential (and thus the strength of the self-generated electric field) is correlated with the oxygen anion coverage which can be well-described by a Langmuir isotherm dependence on the oxygen pressure and oxidation temperature..$^{23,24,36}$ For instance, under a constant oxygen pressure a higher oxidation temperature results in a thinner limiting thickness of the oxide film on $\mathrm{Al}(111)$ due to a reduction of the surface coverage of oxygen ions with increasing oxidation temperature. ${ }^{36}$ It can be noted that the oxidation at $300{ }^{\circ} \mathrm{C}$ results in a faster initial growth rate of the oxide film than that at $25{ }^{\circ} \mathrm{C}$, but the latter takes less time to reach the limiting thickness of the oxide film at the lower temperature; i.e., the limiting thickness of the oxide films actually increases with increasing the temperature for the same water vapor exposure. As noted from Figure 7, an increase in the water vapor pressure by 6 orders of magnitude (i.e., $p\left(\mathrm{H}_{2} \mathrm{O}\right)=1$ Torr $)$ at $25{ }^{\circ} \mathrm{C}$ results in a limiting thickness of the passivating layer that is only slightly thicker than that by water vapor exposure at $300{ }^{\circ} \mathrm{C}$ and $p\left(\mathrm{H}_{2} \mathrm{O}\right)=1 \times 10^{-5}$ Torr.

Such a temperature effect on the limiting thicknesses of the passivating films can be attributed to the transport velocity of $\mathrm{Al}$ from deeper layers of the NiAl substrate to the oxide/alloy interface during the oxide film growth. As schematically shown in Figure 8a, the selective oxidation of $\mathrm{Al}$ results in a $\mathrm{Ni}$-rich interfacial layer. Continued oxide film growth requires dissolution of the interfacial $\mathrm{Ni}$ atoms into the bulk and segregation of $\mathrm{Al}$ atoms from the bulk to the oxide/alloy interface. For water vapor exposure at room temperature, however, the topmost $1-2 \AA$ of the alloy surfaces of $\mathrm{Al}$ is depleted, resulting in a Ni-rich layer that blocks further supply of $\mathrm{Al}$ atoms to the oxide/substrate interface. Thus, despite a larger amount of adsorbed $\mathrm{OH}^{-}$on the surface at the lower temperature that facilitates the development of a stronger Mott potential for field-driven diffusion in the passivating film, the oxide film grows to a less extent of the limiting thickness due to depletion of $\mathrm{Al}$ at the oxide/alloy interface. However, a strengthened Mott potential, which can be achieved by significantly increasing the surface coverage of dissociated water molecules, can facilitate the transport of $\mathrm{Al}$ atoms from the inner layers of the $\mathrm{NiAl}$ substrate through the $\mathrm{Ni}$ interfacial layer to the oxide film, thereby making the oxide film growth again. According to the Langmuir isotherm for the dissociative adsorption, the surface coverage of adsorbed species increases with increasing gas pressure. As seen in Figure 8, an increase in the water vapor pressure over 6 orders of magnitude from $p\left(\mathrm{H}_{2} \mathrm{O}\right)=1 \times 10^{-8}$ to $1 \times 10^{-2}$ Torr results in the growth of the passivating film to a new limiting thickness.
For water vapor exposure at $300{ }^{\circ} \mathrm{C}$, the diffusion of $\mathrm{Al}$ that has reacted for oxide growth is adequately counterbalanced by $\mathrm{Ni}$ diffusion in the opposite direction toward the bulk, thereby sufficiently maintaining an equilibrium stoichiometry at the oxide/alloy interface (schematically shown in Figure 8b). Thus, the oxide film is governed truly by the electric-field-controlled diffusion of $\mathrm{Al}$ through the oxide film due to the supply of sufficient $\mathrm{Al}$ atoms to the oxide/alloy interface to sustain the oxide film growth to the full extent of the limiting thickness controlled by the Mott potential developed at the temperature and pressure.

Tables 2 and 3 list the binding energies of the oxidic $\mathrm{Al} 2 \mathrm{p}, \mathrm{O}$ $1 \mathrm{~s}$, and $\mathrm{OH}$ maxima obtained from the oxide films at their limiting thicknesses for water vapor exposure at 25 and $300{ }^{\circ} \mathrm{C}$ with the different vapor pressures. The observed energetic shifts to the higher binding energies of the oxidic $\mathrm{Al} 2 \mathrm{p}$ and $\mathrm{O} 1 \mathrm{~s}$ peak associated with the growth of the $\mathrm{Al}_{2} \mathrm{O}_{3}$ layer with increasing the oxidation temperature are in good agreement with the temperature-dependent oxidation experiments performed on $\mathrm{Al}$, where a difference in binding energy of up to 0.9 $\mathrm{eV}$ for both the oxidic $\mathrm{Al} 2 \mathrm{p}$ and $\mathrm{O} 1$ s lines was reported for $\mathrm{Al}_{2} \mathrm{O}_{3}$ films formed at room temperature and $600{ }^{\circ} \mathrm{C} .{ }^{37,38}$ Similar temperature-dependent energetic shifts of the oxidic $\mathrm{Al}$ $2 \mathrm{p}$ and $\mathrm{O} 1 \mathrm{~s}$ were also observed from our earlier XPS measurements of the oxide films on $\mathrm{NiAl}(100)$ oxidized by oxygen gas. ${ }^{15}$ In general, the amount of a chemical shift is known to scale rather well with the number of heterogeneous chemical bonds; a larger chemical shift can be attributed to a larger coordination number, on average. ${ }^{14,15}$ For the oxidation of $\mathrm{Al}$ and $\mathrm{NiAl}$, the oxide films formed at the relatively low temperatures $\left(<200{ }^{\circ} \mathrm{C}\right.$ for $\mathrm{Al}$ and $<500{ }^{\circ} \mathrm{C}$ for $\left.\mathrm{NiAl}\right)$ are amorphous in nature and can be described by a close packing of oxygen anions with $\mathrm{Al}$ cations distributed over the octahedral and/or tetrahedral interstices and exhibit a deficiency of $\mathrm{Al}$ cations. ${ }^{15,35,37,39-41}$ Indeed, the stoichiometry of the oxide films formed from the water vapor oxidation at $25{ }^{\circ} \mathrm{C}$ is approximately $\mathrm{Al}_{(2-x)} \mathrm{O}_{3}$ where $x \sim 0.24$, as determined from the XPS $\mathrm{Al} / \mathrm{O}$ peak intensity ratio. For the oxidation at $300{ }^{\circ} \mathrm{C}$ the passivating films become nearly stoichiometric alumina at the limiting thickness. For both temperatures, the compositions of the oxide films are practically independent of the water vapor pressure. Thus, the chemical shifts of the oxidic $\mathrm{Al} 2 \mathrm{p}$ and $\mathrm{O} 1 \mathrm{~s}$ peak toward a higher binding energy reflect the development of more compact alumina films having increased coordination numbers at the elevated temperature.

While the peak positions of the oxidic $\mathrm{Al} 2 \mathrm{p}$ and $\mathrm{O} 1 \mathrm{~s}$ are independent of the water vapor pressure for both the temperatures, the binding energy of the XPS peak associated with the growth of the aluminum hydroxide $\left(\mathrm{Al}(\mathrm{OH})_{3}\right)$ shows clear dependence on the water vapor pressure for the oxidation at room temperature. As seen from Table 1 and Figure 6, the peak maxima of the $\mathrm{OH}$ spectra obtained from the roomtemperature passivating films at their limiting thicknesses shift to the lower binding energies with increasing the water vapor pressure. Such a water vapor pressure dependent energetic shift can be understood similarly from the evolution of the number of heterogeneous chemical bonds in the $\mathrm{Al}(\mathrm{OH})_{3}$ layer. As described above, the water vapor exposure at $25{ }^{\circ} \mathrm{C}$ results in the formation of a Ni-rich interfacial layer, which slows down the supply of $\mathrm{Al}$ atoms to the outer surface to react with adsorbed $\mathrm{OH}$ to form $\mathrm{Al}(\mathrm{OH})_{3}$. Therefore, the growth of a thicker passivating layer at room temperature due to the higher water vapor pressure results in a thicker Ni-rich layer at the 
oxide/alloy interface, which impedes the supply of $\mathrm{Al}$ for the aluminum hydroxide growth. Thus, the $\mathrm{Al}(\mathrm{OH})_{3}$ layer developed at the higher water vapor pressure has a more open structure (i.e., having more dangling bonds due to the deficiency of $\mathrm{Al}$ ions) compared to the thinner film formed under the lower vapor pressure, resulting in a chemical shift to the smaller binding energy (note that the binding energy of oxidic $\mathrm{Al} \mathrm{2p}$ and $\mathrm{O} 1 \mathrm{~s}$ associated with the inner $\mathrm{Al}_{2} \mathrm{O}_{3}$ layer is independent of the water vapor pressure, suggesting that the chemical environments in the inner $\mathrm{Al}_{2} \mathrm{O}_{3}$ film formed from the $\mathrm{Al}(\mathrm{OH})_{3}$ dehydration is not sensitive to the structure feature of the $\mathrm{Al}(\mathrm{OH})_{3}$ precursor). This is in contrast to the temperature effect for which a higher oxidation temperature results in a more compact oxide film structure and thus a chemical shift to the larger binding energy.

\section{CONCLUSIONS}

We report a comparative study of the water-vapor oxidation of $\mathrm{NiAl}(100)$ surface at 25 and $300{ }^{\circ} \mathrm{C}$ with increasing water vapor pressure. The passivation of the $\mathrm{NiAl}(100)$ surface at 25 ${ }^{\circ} \mathrm{C}$ occurs via the growth of a $\mathrm{Al}(\mathrm{OH})_{3} / \mathrm{Al}_{2} \mathrm{O}_{3}$ bilayer thin film, in which the growth of the inner $\mathrm{Al}_{2} \mathrm{O}_{3}$ layer is via the dehydration of the outer $\mathrm{Al}(\mathrm{OH})_{3}$ layer. The passivation of the $\mathrm{NiAl}(100)$ surface at $300{ }^{\circ} \mathrm{C}$ occurs via the growth of a single $\mathrm{Al}_{2} \mathrm{O}_{3}$ layer without involving the intermediate hydroxide phase of $\mathrm{Al}(\mathrm{OH})_{3}$. It is also shown that the water-vapor oxidation at $25{ }^{\circ} \mathrm{C}$ results in a Ni-rich layer at the oxide/alloy interface that impedes the supply of $\mathrm{Al}$ atoms to outer surface for the hydration reaction, whereby resulting in a more Al-deficient structure of the outer $\mathrm{Al}(\mathrm{OH})_{3}$ layer, as evidenced by the chemical shift of the hydroxide associated XPS peak to the lower binding energy upon increasing the vapor pressure. On the contrary, increasing the oxidation temperature results in the growth of a more compact $\mathrm{Al}_{2} \mathrm{O}_{3}$ passivating film as evidenced by the observed chemical shift of the oxidic $\mathrm{Al} 2 \mathrm{p}$ and $\mathrm{O} 1 \mathrm{~s}$ peaks to the higher binding energies at the higher reaction temperature.

\section{AUTHOR INFORMATION}

\section{Corresponding Author}

*E-mail gzhou@binghamton.edu (G.Z.).

\section{Notes}

The authors declare no competing financial interest.

\section{ACKNOWLEDGMENTS}

This work was supported by the National Science Foundation Grant CBET-0932814. Research carried out in part at the Center for Functional Nanomaterials, Brookhaven National Laboratory, which is supported by the U.S. Department of Energy, Office of Basic Energy Sciences, under Contract DEAC02-98CH10886.

\section{REFERENCES}

(1) Thiel, P. A.; Madey, T. E. The interaction of water with solid surfaces: Fundamental aspects. Surf. Sci. Rep. 1987, 7 (6-8), 211-385.

(2) Henderson, M. A. The interaction of water with solid surfaces: fundamental aspects revisited. Surf. Sci. Rep. 2002, 46 (1-8), 1-308.

(3) Pint, B. A.; Hayes, J. A.; Zhang, Y.; More, K. L.; Wright, I. G. The effect of water vapor on the oxidation behavior of Ni-Pt-Al coatings and alloys. Surf. Coat. Technol. 2006, 201, 3852-3856.

(4) Zhao, W.; Gleeson, B. Steam effects on the oxidation behaviour of $\mathrm{Al}_{2} \mathrm{O}_{3}$-scale forming Ni-based alloys. Oxid. Met. 2013, 79, 613-625.
(5) Maurice, V.; Bennour, I.; Zanna, S.; Klein, L. H.; Marcus, P. Modifications and growth mechanisms of ultrathin alumunum oxide films on NiAl in water. J. Phys. Chem. C 2010, 114 (15), 7132-7140.

(6) Maurice, V.; Fremy, N. Maurice, P. Hydroxylation-induced modifications of the $\mathrm{Al}_{2} \mathrm{O}_{3} / \mathrm{NiAl}(001)$ surface at low water vapour pressure. Surf. Sci. 2005, 581 (1), 88-104.

(7) Garza, M.; Magtoto, N. P.; Kelber, J. A. Characterization of oxidized $\mathrm{NiAl}(110)$ and interaction of the oxide film with water vapor. Surf. Sci. 2002, 519, 259-268.

(8) Harbison, J. P.; Sands, T.; Tanatabaie, N.; Chan, W. K.; Florez, L. T.; Keramidas, V. G. Molecular beam epitaxial growth of ultrathin buried metal layers: (Al, Ga)As/NiAl/(Al, Ga)As heterostructures. Appl. Phys. Lett. 1988, 53 (18), 1717-1719.

(9) Sands, T.; Harbison, J. P.; Chan, W. K.; Schwarz, S. A.; Chang, C. C.; Palmstrom, C. J.; Keramidas, V. G. Epitaxial growth of GaAs/NiAl/ GaAs heterostructures. Appl. Phys. Lett. 1988, 52 (15), 1216-1218.

(10) Gong, K.; Luo, H. L.; Feng, D.; Li, C. H. Ni $\mathrm{Ni}_{3} \mathrm{Al}$-based intermetallic alloys as a new type of high-temperature and wearresistant materials. J. Iron Steel Res. Int. 2007, 14 (5), 21-25.

(11) Li, S. P.; Feng, D.; Luo, H. L.; Zhang, X.; Cao, X. Development of new wear-resistant surface coating at elecated temperature. J. Iron Steel Res. Int. 2006, 13 (5), 37-40.

(12) Cabrera, N.; Mott, N. F. Theory of the oxidation of metals. Rep. Prog. Phys. 1949, 12, 163-184.

(13) Battye, F. L.; Jenkin, J. G.; Liesegang, J.; Leckey, R. C. G. Photoelectron determination of the attenuation of low-energy electrons in $\mathrm{Al}_{2} \mathrm{O}_{3}$. Phys. Rev. B 1974, 9, 2887-2893.

(14) Graupner, H.; Hammer, L.; Heinz, K.; Zehner, D. M. Oxidation of low-index FeAl surfaces. Surf. Sci. 1997, 380 (2-3), 335-351.

(15) Cai, N.; Qin, H. L.; Tong, X.; Zhou, G. W. Growth of ultrathin aluminum oxide film during the initial oxidation of $\mathrm{NiAl}(100)$. Surf. Sci. 2013, 618, 20-26.

(16) Lu, Z. W.; Wei, S.-H.; Zunger, A. Theory of bonding charge density in NiAl. Acta Metall. Mater. 1992, 40 (9), 2155-2165.

(17) Gao, Y. F.; Nagai, A.; Masuda, Y.; Sato, F.; Seo, W. S.; Koumoto, K. Surface precipitation of highly porous hydrotalcite-like film on $\mathrm{Al}$ from a zinc aqueous solution. Langmuir 2006, 22, 3521-3527.

(18) Rotole, J. A.; Sherwood, P. M. A. Valence band X-ray photoelectron spectroscopic studies to distinguish between oxidized aluminum species. J. Vac. Sci. Technol., A 1999, 17, 1091-1096.

(19) Alvarez-Barcia, S.; Flores, J. R. The oxidation of Al atoms embedded in water clusters: A dynamical study of the relay (Grotthuss-like) mechanism. J. Chem. Phys. 2011, 134, 244305.

(20) Legare, P.; Fritsch, A. XPS study of transition metal/alumina model catalysts: Equilibrium and energy referencing. Surf. Interface Anal. 1990, 15 (11), 698-700.

(21) Cai, N.; Zhou, G. W.; Muller, K.; Starr, D. E. Comparative study of the passivation of $\mathrm{Al}(111)$ by molecular oxygen and water vapor. $J$. Phys. Chem. C 2013, 117, 172-178.

(22) Qin, H. L.; Zhou, G. W. The formaiton of double-row oxide stripes during the initial oxidation of $\mathrm{NiAl}(100)$. J. Appl. Phys. 2013, 114 (8), 083513.

(23) Cai, N.; Zhou, G. W.; Muller, K.; Starr, D. E. Tuning the limiting-thickness of a thin oxide layer on $\mathrm{Al}$ (111) with oxygen gas pressure. Phys. Rev. Lett. 2011, 107, 035502.

(24) Cai, N.; Zhou, G. W.; Muller, K.; Starr, D. E. Effect of oxygen gas pressure on the kinetics of alumina film growth during the oxidation of $\mathrm{Al}(111)$ at room temperature. Phys. Rev. B 2011, 84, 125445 .

(25) Jaeger, R. M.; Kuhlenbeck, H.; Freund, H.-J. Formation of a well-ordered aluminum oxide overlayer by oxidation of $\mathrm{NiAl}(110)$. Surf. Sci. 1991, 259, 235-252.

(26) CRC Handbook of Chemistry and Physics, 52nd ed.; CRC Press: Raton, FL, 1971/1972.

(27) Freund, H.-J. Oxide surfaces. Faraday Discuss. 1999, 114, 1-31.

(28) Evecen, M.; Cakmak, M. First-principle studies of dissociative adsorption of $\mathrm{H}_{2} \mathrm{O}$ on $\mathrm{NiAl}(110)-(2 \times 2)$ surface. Surf. Interface Anal. 2010, 42 (6-7), 1326-1329. 
(29) Paul, J.; Hoffmann, F. M. Decomposition of water on clean and oxidized aluminum (100). J. Phys. Chem. 1986, 90, 5321-5324.

(30) Digne, M.; Sautet, P.; Raybaud, P.; Toulboat, H.; Artacho, E. Structure and stability of aluminum hydroxides: a theoretical study. $J$. Phys. Chem. B 2002, 106, 5155-5162.

(31) Euzen, P.; Raybaud, P.; Krokidis, X.; Toulhoat, H.; Le Loarer, J.L.; Froidefond, C. Other oxides and alumina. In Handbook of Porous Materials; Schuth, F., Sing, K., Weitkamp, J., Eds.; Wiley-VCH Verlag $\mathrm{GmbH}$ : Weinheim, Germany, 2002; pp 1591-1676.

(32) Cocke, D. L.; Johnson, E. D.; Merrill, R. P. Planar models for alumina-based catalysts. Catal. Rev.-Sci. Eng. 1984, 26 (2), 163-231.

(33) Benndorf, C.; Nobl, C.; Rusenberg, M.; Thieme, F. $\mathrm{H}_{2} \mathrm{O}$ interaction with $\mathrm{Ni}(110)$ : auto-catalytic decomposition in the temperature range from 400 to $550 \mathrm{~K}$. Appl. Surf. Sci. 1982, 11/12, 803-811.

(34) Fujii, C. T.; Meussner, R. A. The mechanism of the hightemperature oxidation of iron-chromium alloys in water vapor. J. Electrochem. Soc. 1964, 111 (11), 1215-1221.

(35) Jeurgens, L. P. H.; Sloof, W. G.; Tichelaar, F. D.; Mittemeijer, E. J. Growth kinetics and mechanism of aluminum-oxide films formed by thermal oxidation of aluminum. J. Appl. Phys. 2002, 92 (3), 16491656.

(36) Cai, N.; Zhou, G. W.; Muller, K.; Starr, D. E. Temperature and pressure dependent Mott potentials and their influence on self-limiting oxide film growth. Appl. Phys. Lett. 2012, 101, 171605.

(37) Jeurgens, L. P. H.; Sloof, W. G.; Tichelaar, F. D.; Mittemeijer, E. J. Composition and chemical state of the ions of aluminium oxide films formed by thermal oxidation of aluminium. Surf. Sci. 2002, 506, 313332.

(38) Jimenez-Gonzalez, A.; Schmelsser, D. Preparation and spectroscopic characterization of $\mathrm{r}-\mathrm{Al}_{2} \mathrm{O}_{3}$ thin films. Surf. Sci. 1991, $250,59-70$.

(39) Jeurgens, L. P. H.; Sloof, W. G.; Tichelaar, F. D.; Mittemeijer, E. J. Thermodynamic stability of amorphous oxide films on metals: Application to aluminum oxide films on aluminum substrates. Phys. Rev. B 2000, 62, 4707.

(40) Jeurgens, L. P. H.; Sloof, W. G.; Tichelaar, F. D.; Mittemeijer, E. J. Structure and morphology of aluminium-oxide films formed by thermal oxidation of aluminium. Thin Solid Films 2002, 418, 89-101. (41) Snijders, P. C.; Jeurgens, L. P. H.; Sloof, W. G. Determination and analysis of oxide-film structure from valance band spectra Application to aluminium oxide films on aluminium substrates. Surf. Sci. 2002, 496, 97-109. 